\title{
PENGARUH FAKTOR INTERNAL, EKSTERNAL, DAN LAYANAN TRANSAKSI DIGITAL BANK TERHADAP PROFITABILITAS
}

\author{
Marizka Distya Anastasia ${ }^{1}$ \\ Munari $^{2}$ \\ 1,2UPN "Veteran" Jawa Timur, Surabaya, Indonesia \\ email: marizkadistyaa@gmail.com
}

\begin{abstract}
ABSTRAK
Salah satu faktor penting bagi perbankan yaitu adanya penilaian kinerja keuangan yang digunakan dalam menggambarkan bank untuk melakukan kinerja yang diukur melalui profitabilitas. Faktor yang menjadi penyebab dalam perubahan profitabilitas bank dapat dilihat dari faktor internal maupun dari faktor eksternal bank serta adanya penerapan teknologi. Penelitian ini bertujuan untuk menganalisis, menguji, dan membuktikan pengaruh CAR, NPL, LDR, BOPO, ukuran perusahaan, inflasi, pertumbuhan ekonomi, transaksi internet banking, dan transaksi mobile banking terhadap profitabilitas bank umum yang terdaftar di Bursa Efek Indonesia tahun 2015-2019. Penelitian ini menggunakan metode kuantitatif dengan data sekunder yang didapatkan melalui laporan keuangan bank yang tersedia di BEI serta website Badan Pusat Statistik (BPS) terkait data inflasi dan pertumbuhan ekonomi. Penentuan sampel menggunakan teknik purposive sampling sehingga diperoleh 6 bank umum untuk diteliti. Teknis analisis data menggunakan regresi linear berganda. Hasil penelitian menunjukkan bahwa CAR berpengaruh positif signifikan terhadap profitabilitas, sedangkan BOPO, pertumbuhan ekonomi, dan transaksi mobile banking berpengaruh negatif signifikan terhadap profitabilitas. Namun, NPL, LDR, ukuran perusahaan, inflasi, dan transaksi internet banking tidak berpengaruh terhadap profitabilitas.
\end{abstract}

Kata kunci: Internet banking; mobile banking; profitabilitas

\begin{abstract}
One of the important factors for banking is financial service providers who describe the bank to perform performance as measured by profitability. Factors that cause changes in bank profitability can be seen from internal factors as well as external factors as well as the application of technology. This study aims to analyze, test, and prove the effect of CAR, NPL, $L D R, B O P O$, company size, inflation, economic growth, internet banking transactions, and mobile banking transactions on the profitability of commercial banks listed on the Indonesia Stock Exchange in 2015-2019. This study uses quantitative methods with secondary data obtained through bank financial reports available on the IDX and the website of the Badan Pusat Satistik (BPS) related to inflation and economic growth data. Determination of the sample using purposive sampling technique in order to obtain 6 commercial banks to be researched. Technical analysis of the data using multiple linear regression. The results showed that CAR has a significant positive effect on profitability, while BOPO, economic growth, and mobile banking transactions have a significant effect on profitability. However, NPL, LDR, company size, inflation, and internet banking transactions have no effect on profitability.
\end{abstract}

Keywords: Internet banking; mobile banking; profitability 


\section{PENDAHULUAN}

Bank merupakan salah satu lembaga keuangan yang memiliki kegiatan utama dalam menghimpun dana masyarakat yang kemudian disalurkan kembali ke masyarakat dan turut serta dalam memberikan layanan perbankan lainnya (Kasmir, 2015). Perbankan sendiri telah memberikan kontribusi pada pertumbuhan ekonomi sebesar 75,8 persen dalam membangkitkan roda perekonomian dibandingkan sektor keuangan lainnya (BI, 2013). Oleh karena itu, peranan perbankan dinilai penting karena jasa atau layanan yang diberikan akan selalu terlibat dalam kehidupan masyarakat (Pinasti \& Mustikawati, 2018). Salah satu faktor penting bagi perbankan yaitu adanya penilaian kinerja keuangan yang digunakan untuk menggambarkan bank dalam melakukan kinerjanya apakah sudah berjalan baik atau sebaliknya (Hendrawan \& Lestari, 2017).

Kinerja perbankan sendiri merupakan suatu hasil yang diperoleh bank ketika mengelola sumber daya yang tersedia secara efektif dan efisien (Trihastuti \& Dewi, 2016). Kinerja perbankan dapat diukur melalui profitabilitas (Sutrisno, 2017). Profitabilitas merupakan acuan untuk menilai kemampuan perusahaan dalam memperoleh laba pada periode tertentu (Dermawan \& Desiana, 2019). Profitabilitas dapat dinilai melalui Return On Asset (ROA). Penggunaan ROA dalam menilai profitabilitas bank dilakukan karena ROA mengukur aset dari dana yang dimiliki bank dimana dana tersebut berasal dari simpanan masyarakat sehingga lebih mewakili dalam penilaian profitabilitas (Avrita \& Pangestuti, 2016).

ROA yang semakin besar akan menunjukkan semakin baik kinerja keuangan perbankan akibat return yang diperoleh juga semakin tinggi (Pramudyani \& Hartono, 2018). Namun, perkembangan ROA bank umum di Indonesia tidak selamanya meningkat seperti yang ditunjukkan pada Tabel 1. dimana data perkembangan ROA bank umum diperoleh dari laporan profil industri perbankan yang didapatkan pada website resmi Otoritas Jasa Keuangan (OJK) (www.ojk.go.id).

Tabel 1.

\begin{tabular}{cc} 
Perkembangan ROA Bank Umum Periode Tahun 2015-2019 \\
\hline Tahun & Return On Asset (ROA) \\
\hline 2015 & $2,32 \%$ \\
2016 & $2,17 \%$ \\
2017 & $2,38 \%$ \\
2018 & $2,55 \%$ \\
2019 & $2,47 \%$ \\
\hline
\end{tabular}

Sumber: Laporan Profil Industri Perbankan, OJK, data diolah, 2021.

Berdasarkan data pada Tabel 1. dapat dilihat bahwa ROA bank umum di Indonesia berfluktuatif dalam 5 tahun terakhir. Pada tahun 2017 sempat mengalami kenaikan sebesar 0,21\% dan pada tahun 2018 mengalami kenaikan sebesar 0,17\%. Selain itu, penurunan nilai ROA sempat terjadi pada tahun 2016 sebesar $0,15 \%$ dan pada tahun 2019 sebesar $0,08 \%$. Adanya penurunan nilai ROA menjadi salah satu permasalahan serta tantangan yang harus dihadapi oleh bank karena dengan adanya penurunan nilai ROA mengakibatkan kinerja keuangan serta performa bank menurun (Pertiwi \& Susanto, 2019). Faktor yang menjadi penyebab dalam perubahan profitabilitas bank dapat dilihat dari faktor internal dimana dapat berasal 
dari rekening bank, kecukupan modal, efisiensi operasional maupun dari faktor eksternal bank yang dapat berasal dari indikator ekonomi makro, kebijakan dan regulasi, hukum, serta adanya penerapan teknologi (Sorongan, 2017).

Pada penelitian sebelumnya, kecukupan modal bank yang dinilai dari CAR terbukti berpengaruh terhadap profitabilitas (Ambarawati \& Abundanti, 2018; Nugroho et al., 2019). Namun dalam beberapa penelitian yang lain menemukan bahwa CAR tidak berpengaruh terhadap profitabilitas (Arofany \& Tandika, 2019; L. N. Hidayati, 2015). Selain itu, juga ada penelitian yang terkait risiko kredit yang diukur dengan Non Performing Loan (NPL) terbukti memiliki pengaruh terhadap profitabilitas (Ambarawati \& Abundanti, 2018; Patni \& Darma, 2017; Sudaryanti et al., 2018). Sedangkan pada penelitian lain terkait NPL ditemukan bahwa NPL tidak berpengaruh terhadap profitabilitas (Harun, 2016; Matindas et al., 2015; Stevani \& Sudirgo, 2019). Penilaian Loan to Deposit Ratio (LDR) juga berpengaruh terhadap profitabilitas (Pertiwi \& Susanto, 2019; Soares \& Yunanto, 2018). Tetapi pada penelitian lain diungkapkan hal yang sebaliknya yaitu LDR tidak berpengaruh terhadap profitabilitas (Siahaan \& Asandimitra, 2018; Stephani et al., 2017).

Variabel lain yang menjadi faktor internal dan dianggap berpengaruh terhadap profitabilitas yaitu Beban Operasional Pendapatan Operasional (BOPO) serta ukuran perusahaan. Pada penelitian yang dilakukan sebelumnya, ditunjukkan bahwa BOPO memiliki pengaruh terhadap profitabilitas bank (Stephani et al., 2017; Stevani \& Sudirgo, 2019). Selain itu pada penelitian terkait ukuran perusahaan juga ditemukan bahwa ukuran perusahaan ikut berpengaruh terhadap profitabilitas (Hendrawan \& Lestari, 2017; Hirindukawshala \& Kushanipanditharathna, 2017). Namun, beberapa penelitian lain diungkapkan bahwa BOPO tidak memiliki pengaruh terhadap profitabilitas (Gunawan et al., 2020), serta pada penelitian lain terkait ukuran perusahaan ditemukan bahwa ukuran perusahaan juga tidak berpengaruh terhadap profitabilitas (Oktaviarni et al., 2018; Putra, 2015).

Faktor eksternal yang juga turut berpengaruh terhadap profitabilitas yaitu inflasi dan pertumbuhan ekonomi. Pada penelitian sebelumnya ditemukan bahwa inflasi berpengaruh terhadap profitabilitas (Dwi Nurfadillah et al., 2019; A. N. Hidayati, 2014). Kemudian pada penelitian yang lain ditemukan bahwa pertumbuhan ekonomi berpengaruh terhadap profitabilitas (Adiyadnya et al., 2016; Sorongan, 2017). Namun dalam penelitian lain terkait inflasi tidak ditemukan adanya pengaruh inflasi terhadap profitabilitas (Adiyadnya et al., 2016; Sorongan, 2017). Begitu juga dengan penelitian lain terkait pertumbuhan ekonomi yang ditemukan tidak adanya pengaruh terhadap profitabilitas (Cahyani, 2018; Sugito \& Winarno, 2019).

Faktor lain yang juga berpengaruh terhadap profitabilitas bank yaitu adanya pemanfaatan dan penerapan teknologi yang memiliki tujuan untuk menghadapi adanya persaingan usaha serta efisiensi kinerja yang dimana penerapan teknologi akan mampu mengurangi biaya operasional perbankan (Yohani \& Dita, 2019). Sektor perbankan merupakan pengguna teknologi informasi yang paling banyak diantara sektor lain (Margaretha, 2015). Teknologi yang digunakan bank yang tercermin dari penggunaan internet banking serta mobile banking dimana hal ini didasarkan pada adanya kenaikan nilai transaksi digital di indonesia yang diperoleh 
dari situs Kata data yang mengungkapkan bahwa nilai transaksi digital di indonesia paling besar di Asia Tenggara yaitu mencapai \$21 Milyar (Kata Data, 2019).

Hal ini juga diperkuat dengan adanya penelitian yang menemukan adanya layanan internet banking berpengaruh terhadap profitabilitas (Wulandari \& Novitasari, 2020). Selain itu, juga adanya penelitian sebelumnya terkait layanan mobile banking yang menemukan bahwa layanan mobile banking juga memiliki pengaruh terdapat mempengaruhi profitabilitas (Arofany \& Tandika, 2019; Okon \& Amaegberi, 2018). Namun pada hasil penelitian yang lain terkait layanan internet banking tidak ditemukan adanya pengaruh layanan intenet banking terhadap profitabilitas (Arif \& Masdupi, 2020; Arofany \& Tandika, 2019), serta pada penelitian lain terkait layanan mobile banking juga ditemukan hasil yang sebaliknya yaitu layanan mobile banking tidak berpengaruh terhadap profitabilitas (Mary Ada et al., 2020).

Berdasarkan hasil penelitian sebelumnya, banyak ditemukan tidak konsistennya pengaruh dari variabel yang digunakan terhadap profitabilitas, sehingga perlunya melakukan penelitian kembali agar dapat menganalisis, menguji, dan membuktikan terkait faktor internal, eksternal serta layanan transaksi digital bank apa saja yang dapat mempengaruhi profitabilitas bank umum yang terdaftar di Bursa Efek Indonesia (BEI) pada tahun 2015-2019. Penelitian ini dilandasi pada enam teori yang akan menjadi dasar penelitian yaitu pecking order theory yang digunakan sebagai dasar pemikiran untuk menjelaskan bagaimana kecukupan modal yang dimiliki bank terhadap profitabilitas melalui variabel Capital Adequacy Ratio (CAR), anticipated income theory yang digunakan untuk dasar pemikiran dalam menjelaskan kredit bermasalah yang dimiliki bank melalui variabel Non Performing Loan (NPL) dan likuiditas bank melalui variabel Loan to Deposit Ratio (LDR) terhadap profitabilitas, signalling theory yang digunakan untuk dasar pemikiran dalam menjelaskan efisiensi bank melalui variabel Beban Operasional Pendapatan Operasional (BOPO) terhadap profitabilitas, critical resource theory yang digunakan untuk dasar pemikiran dalam menjelaskan ukuran perusahaan terhadap profitabilitas, keynesian theory yang digunakan untuk dasar pemikiran dari pengaruh faktor eksternal melalui variabel inflasi dan pertumbuhan ekonomi terhadap profitabilitas, dan resource based view theory yang digunakan untuk dasar pemikiran dalam menjelaskan pemanfaatan sumber daya internal sebagai strategi bersaing melalui variabel internet banking dan mobile banking terhadap profitabilitas.

Capital Adequacy Ratio (CAR) adalah rasio permodalan yang memperlihatkan kesanggupan bank untuk mencadangkan dana dalam kebutuhan pengembangan bisnis maupun risiko adanya kerugian dana dalam operasional bank (Avrita \& Pangestuti, 2016). CAR akan menunjukkan seberapa besar modal bank itu sendiri terhadap risiko yang ditimbulkan dari kegiatan operasional (Bilian \& Purwanto, 2017). Ketika CAR yang dimiliki bank semakin tinggi, maka akan semakin baik kemampuan bank untuk menanggung sebuah risiko yang diakibatkan (L. N. Hidayati, 2015).

Hal ini akan sesuai dengan pecking order theory dalam menjelaskan CAR sebagai kecukupan modal yang dimiliki bank dimana CAR dapat menunjukkan bahwa dengan pendanaan internal akan meminimalisir risiko yang ditimbulkan dari 
adanya kegiatan operasional bank. Dengan adanya risiko yang kecil dalam operasional bank akan meningkatkan nilai profitabilitas yang diukur melalui ROA. Teori ini juga didukung dengan adanya penelitian sebelumnya yang menemukan bahwa CAR memiliki pengaruh positif signifikan terhadap profitabilitas (Ambarawati \& Abundanti, 2018; Kossoh et al., 2017; Nugroho et al., 2019), sehingga perumusan hipotesis:

$\mathrm{H}_{1}$ : CAR berpengaruh positif signifikan terhadap profitabilitas.

Non Performing Loan (NPL) merupakan rasio yang dapat menunjukkan kemampuan bank dalam mengendalikan kredit bermasalah (Stevani \& Sudirgo, 2019). NPL yang meningkat akan memperlihatkan semakin buruk kualitas kredit yang diberikan bank karena semakin banyak kredit bermasalah yang kemudian menyebabkan kerugian (Stephani et al., 2017).

Sesuai dengan anticipated income theory dimana pengembalian kredit atau pembayaran kredit yang telah diberikan bank yang tidak dapat dilakukan secara tepat waktu dapat memunculkan risiko kredit macet atau bermasalah yang akan menimbulkan kerugian. Besarnya nilai NPL akan memperlihatkan besarnya kredit bermasalah yang akan berpengaruh pada tingkat profitabilitas yang diukur dengan ROA menjadi rendah. Selain itu, teori ini juga didukung dengan adanya penelitian yang menemukan bahwa NPL berpengaruh secara negatif signifikan terhadap profitabilitas (Ambarawati \& Abundanti, 2018; Patni \& Darma, 2017; Sudaryanti et al., 2018). Perumusan hipotesis:

$\mathrm{H}_{2}$ : NPL berpengaruh negatif signifikan terhadap profitabilitas

Loan to Deposit Ratio (LDR) merupakan rasio yang menilai kemampuan bank dalam melakukan pembayaran kembali dana pihak ketiga kepada nasabah dengan menyalurkan kredit sebagai sumber likuiditas bank itu sendiri (Stephani et al., 2017). Rasio LDR yang semakin tinggi diimbangi dengan kemampuan bank dalam memberikan kredit secara efektif akan meningkatkan laba yang juga ikut berpengaruh terhadap profitabilitas sehingga nilai profitabilitas ikut meningkat (Pertiwi \& Susanto, 2019).

Teori terkait dengan hubungan LDR yaitu anticipated income theory dimana bank seharusnya bisa menjaga likuiditasnya dengan kemampuan dalam membayar dana pihak ketiga serta memberikan kredit secara efektif dan mampu membayar hutang bank itu sendiri secara tepat waktu agar bank tidak mengalami kerugian. Nilai LDR yang besar diimbangi dengan efektifitas penyaluran kredit dan kemampuan dalam membayar kembali dana pihak ketiga kepada nasabah akan meningkatkan kinerja keuangan yang akhirnya berpengaruh terhadap profitabilitas sehingga nilai profitabilitas yang diukur dengan ROA akan semakin meningkat. Adanya penelitian sebelumnya turut mendukung teori yang menemukan bahwa LDR memiliki ppengaruh positif signifikan terhadap profitabilitas (Ambarawati \& Abundanti, 2018; Pertiwi \& Susanto, 2019). Perumusan hipotesis:

$\mathrm{H}_{3}$ : LDR berpengaruh positif signifikan terhadap profitabilitas.

BOPO merupakan rasio yang dapat menilai effisiensi bank serta kesanggupan bank dalam mengelola kegiatan operasionalnya (Jorjoga \& Murdayanti, 2015). Rasio BOPO yang semakin rendah akan menunjukkan semakin baik kinerja bank dikarenakan manajemen bank mempergunakan sumber daya yang ada di bank secara efisien (Stephani et al., 2017). 
Berkaitan dengan hubungan rasio BOPO terdapat signalling theory dimana keterbukaan informasi dalam laporan keuangan untuk perhitungan rasio BOPO yang menggambarkan beban manajemen akan memberikan sinyal apakah bank dapat mengelola sumber daya yang ada secara efisien. Dengan adanya efisiensi pada beban manajemen akan mempengaruhi kinerja yang dinilai dengan profitabilitas melalui penilaian ROA dimana dengan rendahnya rasio BOPO akan menyebabkan keuntungan akibat beban yang akan ditanggung oleh pihak bank lebih rendah sehingga akan meningkatkan profitabilitas. Penelitian sebelumnya terikait BOPO juga mendukung teori yang ada, yaitu ditemukan bahwa BOPO berpengaruh negatif signifikan terhadap profitabilitas (Pinasti \& Mustikawati, 2018; Stephani et al., 2017), sehingga perumusan hipotesis:

$\mathrm{H}_{4}$ : BOPO berpengaruh negatif signifikan terhadap profitabilitas.

Ukuran perusahaan akan memperlihatkan besar kecilnya suatu perusahaan (Arif \& Masdupi, 2020). Ukuran perusahaan dapat diukur melalui jumlah aset yang dimiliki oleh bank tersebut (N. Setiawan et al., 2018). Perusahaan yang besar akan memiliki aset yang besar pula yang akan menunjukkan jika aset yang dimiliki suatu perusahaan tersebut besar maka profitabilitas yang dimiliki perusahaan tersebut akan ikut tinggi karena memiliki efesiensi dalam kegiatan operasionalnya (Vernanda \& Widyarti, 2016).

Critical resource theory merupakan teori yang berkaitan dengan ukuran perusahaan, menekankan faktor yang akan menetapkan ukuran perusahaan yang diperoleh dari adanya pengendalian pemilik perusahaan terhadap sumber daya usaha dengan menggambarkan besar kecilnya ukuran perusahaan melalui total aset yang dimiliki dan akan berkaitan dengan profitabilitas. Dengan besarnya ukuran suatu perusahaan akan menunjukkan bahwa aset yang dimiliki perusahaan tersebut besar serta akan memiliki efiensi dalam kegiatan operasional karena adanya keuntungan dari pengurangan biaya produksi ketika perusahaan berproduksi secara besar dengan sumber daya yang sama sebab perusahaan yang besar sanggup dalam mencapai skala ekonomisnya sehingga profitabilitas yang diukur melalui ROA juga akan meningkat. Adanya critical resource theory juga didukung dengan beberapa penelitian sebelumnya yang menemukan bahwa ukuran perusahaan berpengaruh positif signifikan terhadap profitabilitas (Hendrawan \& Lestari, 2017; Hirindukawshala \& Kushanipanditharathna, 2017), sehingga perumusan Hipotesis: $\mathrm{H}_{5}$ : Ukuran perusahaan berpengaruh positif signifikan terhadap profitabilitas.

Inflasi merupakan kenaikan harga umum yang cenderung terus menerus dalam kurun waktu yang lama (Anugrah et al., 2020). Inflasi akan membuat jumlah uang yang beredar di masyarakat semakin banyak karena pengeluaran uang untuk konsumsi lebih besar dibanding untuk menyimpan uang di bank (Pramudyani \& Hartono, 2018). Meningkatnya inflasi membuat nilai riil tabungan menurun akibat masyarakat hanya menggunakan hartanya guna mencukupi biaya pengeluaran yang diakibatkan oleh naiknya harga barang yang kemudian akan berpengaruh pada profitabilitas bank itu sendiri (Adiyadnya et al., 2016).

Teori yang mendukung hubungan inflasi yaitu keynesian theory, dimana ketika terjadi inflasi akan membuat jumlah uang beredar semakin banyak karena inflasi sendiri merupakan kenaikan harga yang terus menerus dalam waktu yang cukup lama sehingga masyarakat dengan penghasilan yang tetap akan kesulitan 
untuk menjangkau harga barang tersebut. Kenaikan harga yang terus menerus akan menyebabkan masyarakat hanya menggunakan hartanya untuk mencukupi kebutuhan akibat meningkatnya harga sehingga nilai riil tabungan menurun dikarenakan rendahnya orang yang menabung di bank yang akhirnya berpengaruh pada profitabilitas bank. Penelitian sebelumnya juga menemukan bahwa inflasi berpengaruh negatif signifikan terhadap profitabilitas (Dwi Nurfadillah et al., 2019; Soeharjoto \& Hariyanti, 2019), sehingga perumusan hipotesis:

$\mathrm{H}_{6}$ : Inflasi berpengaruh negatif signifikan terhadap profitabilitas.

Pertumbuhan ekonomi merupakan peningkatan kemampuan ekonomi ketika menghasilkan barang dan jasa (Arif \& Masdupi, 2020). Pertumbuhan ekonomi suatu negara dinilai dengan Produk Domestik Bruto (PDB) (Lubis, 2014). Pertumbuhan ekonomi yang meningkat akan menaikkan daya beli masyarakat yang menyebabkan konsumsi barang dan jasa meningkat (Anugrah et al., 2020). Penilaian pertumbuhan ekonomi dengan PDB akan berpengaruh terhadap pola saving seseorang, sehingga PDB yang semakin naik juga akan meningkatkan profitabilitas bank (Adiyadnya et al., 2016).

Sesuai dengan keynesian theory dimana pertumbuhan ekonomi akan terjadi apabila suatu negara tidak mengalami inflasi. Dengan tidak terjadinya inflasi, maka daya beli masyarakat ikut meningkat dan konsumsi barang dan jasa ikut meningkat serta akan meningkatkan pola saving dimana harta yang dimiliki masyarakat tidak hanya digunakan untuk membeli barang. Masyarakat dapat menyalurkan uangnya di bank dan hal tersebut akan mempengaruhi profitabilitas bank semakin meningkat. Selain itu, teori ini juga didukung dengan adanya penelitian sebelum yang menemukan bahwa pertumbuhan ekonomi yang dinilai melalui PDB berpengaruh positif terhadap profitabilitas (Adiyadnya et al., 2016; Sorongan, 2017), sehingga perumusan hipotesis:

$\mathrm{H}_{7}$ : Pertumbuhan ekonomi berpengaruh negatif signifikan terhadap profitabilitas.

Internet banking merupakan layanan yang ditawarkan bank dengan media internet dalam bertransaksi maupun melakukan aktivitas perbankan lainnya (Arofany \& Tandika, 2019). Penggunaan internet banking dapat meningkatkan ROA secara terus menerus dan signifikan (Wulandari \& Novitasari, 2020). Penerapan layanan digital pada perbankan mampu memperluas pangsa pasar bank dan jangkauan produk, serta dapat mengurangi biaya operasional bank yang kemudian berkontribusi meningkatkan kinerja bank yang berkaitan dengan profitabilitas. (Arofany \& Tandika, 2019).

Resource based view theory merupakan teori yang mendukung hubungan internet banking dimana penggunaan internet banking merupakan cara perusahaan untuk memanfaatkan sumber daya internal dalam mengahadapi persaingan industri perbankan yang kemudian akan meningkatkan kinerja yang diukur melalui profitabilitas bank. Pada penelitian sebelumnya juga ditemukan bahwa internet banking berpengaruh positif signifikan terhadap profitabilitas (Wulandari \& Novitasari, 2020; Yasin, 2018), sehingga perumusan hipotesis:

$\mathrm{H}_{8}$ : Transaksi internet banking berpengaruh positif signifikan terhadap profitabilitas

Mobile Banking merupakan salah satu layanan transaksi digital perbankan yang dapat diakses melalui aplikasi yang sudah di install sebelumnya pada 
smartphone nasabah (Arofany \& Tandika, 2019). ROA disinyalir dapat meningkat dari adanya penggunaan teknologi informasi karena bank lebih memudahkan nasabah untuk bertransaksi sehingga transaksi nasabah turut meningkat serta bank juga lebih efisien dalam melayani nasabah (Sudaryanti et al., 2018). Penerapan layanan digital pada perbankan mampu memperluas pangsa pasar bank dan jangkauan produk, serta dapat mengurangi biaya operasional bank yang kemudian berkontribusi meningkatkan kinerja bank yang berkaitan dengan profitabilitas. (Arofany \& Tandika, 2019).

Teori terkait penggunaan mobile banking yaitu resource based view theory yang menjelaskan bahwa adanya penggunaan mobile banking adalah salah satu cara perusahaan dalam memanfaatkan sumber daya internal perusahaan tersebut untuk menghadapi persaingan industri yang akhirnya mampu meningkatkan kinerja melalui profitabilitas. Teori ini juga didukung dengan adanya penelitian sebelum yang menemukan bahwa transaksi mobile banking berpengaruh positif signifikan terhadap profitabilitas (Arofany \& Tandika, 2019; Okon \& Amaegberi, 2018), sehingga perumusan hipotesis:

$\mathrm{H}_{9}$ : Transaksi mobile banking berpengaruh positif signifikan terhadap profitabilitas.

\section{METODE PENELITIAN}

Jenis penelitian ini adalah penelitian kuantitatif dimana penelitian ini memiliki tujuan untuk menguji hipotesis yang telah ditentukan guna meneliti populasi atau sampel tertentu dengan menggunakan instrumen penelitian dalam pengumpulan data serta analisis data bersifat kuantitatif atau statistik (Sugiyono, 2015). Penelitian ini menggunakan data sekunder yang diperoleh dari data laporan keuangan tahunan bank umum yang terpublikasi di Bursa Efek Indonesia (BEI), serta data pada website Badan Pusat Statistik (BPS) terkait data inflasi dan pertumbuhan ekonomi. Variabel yang digunakan dalam penelitian ini ada dua, variabel dependen $(\mathrm{Y})$ yaitu profitabilitas yang diukur dengan ROA dan variabel independen $(\mathrm{X})$ yang diukur dengan CAR, NPL, LDR, BOPO, ukuran perusahaan, inflasi, pertumbuhan ekonomi, transaksi internet banking serta transaksi mobile banking.

ROA merupakan salah satu rasio profitabilitas yang dapat digunakan untuk melihat keuntungan yang dihasilkan dari kemampuan keseluruhan suatu perusahaan dengan keseluruhan aktiva yang ada dalam perusahaan (Yultiara \& Nurdin, 2018) ROA dapat dihitung dengan rumus (Riyadi, 2015):

$$
\text { ROA }=\frac{\text { Laba Sebelum Pajak }}{\text { Rata-Rata Total Aset }} \times 100 \%
$$

CAR merupakan rasio yang menunjukkan jumlah keseluruhan aktiva bank yang memuat risiko yang dibayarkan dari modal bank sendiri (Ginting, 2019). CAR dapat dihitung dengan rumus (Riyadi, 2015):

$$
\mathrm{CAR}=\frac{\text { Modal }}{\mathrm{ATMR}} \times 100 \%
$$

NPL adalah rasio perbandingan antara kredit macet dengan dengan jumlah kredit yang diberikan untuk menghitung risiko kredit yang diberikan (Kasmir, 2019). NPL dapat dihitung dengan rumus (Riyadi, 2015):

$$
\text { NPL }=\frac{\text { Total Kredit Bermasalah }}{\text { Total Kredit }} \times 100 \%
$$


LDR merupakan rasio yang membandingkan antara total kredit yang diberikan oleh pihak bank dengan dana pihak ketiga yang diperoleh bank (Pramudyani \& Hartono, 2018). LDR dapat dihitung dengan rumus (Riyadi, 2015):

$$
\text { LDR }=\frac{\text { Total Kredit yang Diberikan }}{\text { Dana Pihak Ketiga }} \times 100 \%
$$

BOPO merupakan rasio yang akan membandingkan biaya operasional bank dengan pendapatan operasional bank itu sendiri (Kurniasari, 2017). BOPO dapat dihitung dengan rumus (Riyadi, 2015):

$$
\text { BOPO }=\frac{\text { Beban Operasional }}{\text { Pendapatan Operasional }} \times 100 \%
$$

Ukuran perusahaan dapat diukur melalui jumlah aset yang dimiliki oleh bank tersebut (N. Setiawan et al., 2018). Ukuran perusahaan dapat dihitung dengan rumus (Pertiwi \& Susanto, 2019):

Ukuran Perusahaan $=\operatorname{Ln}($ Total Aset $)$.

Inflasi dalam penelitian ini diukur melalui indikator yang umum digunakan untuk mengukur tingkat inflasi di indonesia yaitu Indeks Harga Konsumen (IHK) (Noor \& Komala, 2019). Inflasi dapat dihitung dengan rumus (Anugrah et al., 2020):

$$
\mathrm{IHK}=\frac{\mathrm{IHK}-\mathrm{IHK}_{t-1}}{\mathrm{IHK}_{t-1}} \times 100 \%
$$

Pertumbuhan ekonomi dalam penelitian ini dinilai dengan Produk Domestik Bruto (PDB). Produk Domestik Bruto (PDB) dapat dihitung dengan rumus (Anugrah et al., 2020):

$$
\mathrm{PDB}=\frac{\mathrm{PDB}-\mathrm{PDB}_{t-1}}{\mathrm{PDB}_{t-1}} \times 100 \%
$$

Dalam mengukur variabel internet banking menggunakan data dari jumlah transaksi internet banking (Arif \& Masdupi, 2020). Sedangkan untuk mengukur variabel mobile banking menggunakan data dari jumlah transaksi mobile banking (Arofany \& Tandika, 2019).

Populasi merupakan seluruh karakteristik dari subjek ataupun objek yang ditentukan untuk dipelajari dan disimpulkan (Sugiyono, 2015). Populasi yang digunakan dalam penelitian ini yaitu Bank Umum yang terdaftar di Bursa Efek Indonesia (BEI) selama tahun 2015-2019 yang terdiri dari 45 bank. Sampel menurut (Sugiyono, 2015) merupakan sebagian dari jumlah serta karakteristik sebuah populasi. Dalam menentukan sampel, digunakan teknik penentuan sampel dengan purposive sampling. Purposive sampling merupakan metode pengambilan sampel dimana penentuan sampel menggunakan pertimbangan tertentu (Sugiyono, 2015).

Kriteria dalam penelitian ini yaitu bank umum yang terdaftar di BEI selama tahun 2015-2019 yang menggunakan layanan internet banking dan mobile banking serta memiliki data keuangan lengkap termasuk melaporkan jumlah transaksi internet banking dan transaksi mobile banking. Bank umum yang masuk kriteria penelitian ini berjumlah 6 bank, sehingga sampel data yang diperoleh melalui purposive sampling sebanyak 30 sampel data yang diperoleh melalui laporan keuangan 6 bank umum yang memenuhi kriteria sampel data dikalikan dengan 5 tahun periode penelitian (2015-2019).

Teknik analisis data menggunakan analisis regresi linear berganda. Dalam penelitian ini analisis regresi linear berganda dengan menggunakan program 
komputer SPSS versi 23. Model dari persamaan regresi yang digunakan dalam penelitian ini, yaitu:

Keterangan:

$$
\mathrm{Y}=\alpha+\beta_{1} X_{1}+\beta_{2} X_{2}+\beta_{3} X_{3}+\beta_{4} X_{4}+\beta_{5} X_{5}+\beta_{6} X_{6}+\beta_{7} X_{7}+\beta_{8} X_{8}+\beta_{9} X_{9}+e . .(9)
$$

\begin{tabular}{|c|c|}
\hline Y & $=$ Return On Asset (ROA) \\
\hline$\alpha$ & $=$ Konstanta \\
\hline$X_{1}$ & $=$ Capital Adequacy Ratio (CAR) \\
\hline $\mathrm{X}_{2}$ & $=$ Non Performing Loan (NPL) \\
\hline $\mathrm{X}_{3}$ & $=$ Loan to Deposit Ratio (LDR) \\
\hline$X_{4}$ & $=$ Beban Operasional Pendapatan Operasional $(\mathrm{BOPO}$ \\
\hline$X_{5}$ & $=$ Ukuran Perusahaan \\
\hline$X_{6}$ & $=$ Inflasi \\
\hline$X_{7}$ & $=$ Pertumbuhan Ekonomi \\
\hline$X_{8}$ & $=$ Jumlah Transaksi Mobile Banking \\
\hline$X_{9}$ & $=$ Jumlah Transaksi Internet Banking \\
\hline$\beta_{1-9}$ & $=$ Koefisien Regresi \\
\hline & $=$ Variabel Eror \\
\hline
\end{tabular}

\section{HASIL DAN PEMBAHASAN}

Analisis statistik deskriptif merupakan gambaran data yang telah terkumpul dari hasil analisis dengan tujuan tidak untuk mengambil kesimpulan secara generalisasi (Sugiyono, 2015). Gambaran data ini didapatkan melalui program SPSS 23 yang didalamnya menjelaskan mengenai nilai terendah, nilai tertinggi, nilai rata-rata, serta standar deviasi pada variabel yang diuji.

Tabel 2.

Analisis Deskriptif

\begin{tabular}{lccccc}
\hline & N & Minimum & Maximum & Mean & Std. Deviation \\
\hline ROA & 30 &, 47 & 4,19 & 2,8173 &, 93733 \\
CAR & 30 & 16,28 & 26,21 & 21,1427 & 2,26654 \\
NPL & 30 &, 70 & 3,96 & 2,4610 &, 83942 \\
LDR & 30 & 55,35 & 98,38 & 84,5347 & 11,67270 \\
BOPO & 30 & 58,20 & 97,38 & 73,2453 & 9,51091 \\
Ukuran Perusahaan & 30 & 31,85 & 36,32 & 33,8937 & 1,07257 \\
Inflasi & 30 & 2,72 & 3,61 & 3,1660 &, 30598 \\
Pertumbuhan Ekonomi & 30 & 4,79 & 5,17 & 5,0140 &, 12681 \\
Transaksi Internet Banking & 30 & 562826 & 2500000000 & 567180611,77 & 778857564,207 \\
Transaksi Mobile Banking & 30 & 782862 & 3800000000 & 524152008,87 & 821248614,039 \\
Valid N (listwise) & 30 & & & & \\
\hline
\end{tabular}

Sumber: Data diolah, 2021.

Berdasarkan pada Tabel 2. diatas menunjukkan jumlah data penelitian yang digunakan sebanyak 30 data yang diperoleh melalui 6 bank umum yang menenuhi syarat penentuan sampel dalam periode waktu penelitian selama 5 tahun (20152019). Profitabilitas yang diukur melalui ROA memiliki nilai rata-rata sebesar 2,8173 persen dengan standar deviasi sebesar 0,93733 persen. Nilai minimum sebesar 0,47 persen yang dimiliki oleh Bank CIMB Niaga pada tahun 2015. Nilai 
maksimum ROA sebesar 4,19 persen yang dimiliki oleh Bank Rakyat Indonesia pada tahun 2015.

Capital Adequacy Ratio (CAR) memiliki nilai rata-rata sebesar 21,1427 persen dengan standar deviasi sebesar 2,26654 persen. Nilai minimum CAR sebesar 16,28 persen yang dimiliki oleh Bank CIMB Niaga pada tahun 2015. Nilai maksimum CAR sebesar 26,21 persen yang dimiliki oleh Bank Mega pada tahun 2016. Non Performing Loan (NPL) memiliki nilai rata-rata sebesar 2,4610 persen dengan standar deviasi sebesar 0,83942 persen. Nilai minimum NPL sebesar 0,70 persen yang dimiliki oleh Bank Central Asia pada tahun 2015. Nilai maksimum NPL sebesar 3,96 persen yang dimiliki oleh Bank Mandiri pada tahun 2016. Loan to Deposit Ratio (LDR) memiliki nilai rata-rata sebesar 84,5347 persen dengan standar deviasi sebesar 11,67270 persen. Nilai minimum LDR sebesar 55,35 persen yang dimiliki oleh Bank Mega pada tahun 2016. Nilai maksimum LDR sebesar 98,38 persen yang dimiliki oleh Bank CIMB Niaga pada tahun 2016. Beban Operasional Pendapatan Operasional (BOPO) memiliki nilai rata-rata sebesar 73,2453 persen dengan standar deviasi sebesar 9,51091 persen. Nilai minimum BOPO sebesar 58,20 persen yang dimiliki oleh Bank Central Asia pada tahun 2018. Nilai maksimum BOPO sebesar 97,38 persen yang dimiliki oleh Bank CIMB Niaga pada tahun 2015. Ukuran perusahaan memiliki nilai rata-rata sebesar 33,8937 dengan standar deviasi sebesar 1,07257. Nilai minimum ukuran perusahaan sebesar 31,85 yang dimiliki oleh Bank Mega pada tahun 2015. Nilai maksimum ukuran perusahaan sebesar 36,32 yang dimiliki oleh Bank Central Asia pada tahun 2015. Inflasi memiliki nilai rata-rata sebesar 3,1660 persen dengan standar deviasi sebesar 0,30598 persen. Nilai minimum inflasi sebesar 2,72 persen yang terjadi pada tahun 2019. Nilai maksimum inflasi sebesar 3,61 persen yang terjadi pada tahun 2017.

Pertumbuhan ekonomi yang tercermin melalui Produk Domestik Bruto (PDB) memiliki nilai rata-rata sebesar 5,0140 persen dengan standar deviasi sebesar 0,12681 persen. Nilai minimum PDB sebesar 4,79 persen yang terjadi pada tahun 2015. Nilai maksimum PDB sebesar 5,17 persen yang terjadi pada tahun 2018 . Transaksi internet banking memiliki nilai rata-rata sebesar Rp 567.180.611,77 dengan standar deviasi sebesar 778.857.564,207. Nilai minimum transaksi internet banking sebesar Rp 562.826 yang dimiliki oleh Bank Mega pada tahun 2015. Nilai maksimum transaksi internet banking sebesar Rp 2.500.000.000 yang dimiliki oleh Bank Central Asia pada tahun 2019. Transaksi mobile banking memiliki nilai ratarata sebesar Rp 524.152.008,87 dengan standar deviasi sebesar 821.248.614,039. Nilai minimum transaksi mobile banking sebesar Rp 782.862 yang dimiliki oleh Bank Mega pada tahun 2015. Nilai maksimum transaksi mobile banking sebesar Rp 3.800.000.000 yang dimiliki oleh Bank Central Asia pada tahun 2019.

Uji normalitas dilakukan untuk melihat apakah model regresi berdistribusi normal atau tidak (Ramadhayanti, 2019). Dalam uji normalitas, model regresi yang baik yaitu model regresi yang berdistribusi normal dan dalam penelitian ini uji normalitas dilakukan dengan uji One Sample Kolmogorov Smirnov dimana pengujian berdasarkan significance level dari hasil Kolmogorov Smirnov (Ghozali, 2016). 
Tabel 3.

Hasil Uji Normalitas

\begin{tabular}{lc}
\hline & Unstandardized Residual \\
\hline $\mathrm{N}$ & 30 \\
Test Statistic &, 124 \\
Asymp. Sig. (2-tailed) &, 200 \\
\hline Sumber: Data diolah, 2021.
\end{tabular}

Berdasarkan Tabel 3. hasil uji normalitas menggunakan kolmogorov-smirnov memperlihatkan nilai asymp.sig (2-tailed) sebesar 0,200 sehingga data yang dimiliki dalam penelitian ini dikatakan berdistribusi normal karena nilai asymp.sig (2-tailed) lebih besar dari taraf signifikan yang telah ditetapkan yaitu sebesar 0,05.

Uji multikolineritas dilakukan untuk melihat apakah terdapat korelasi antar variabel independen (Ramadhayanti, 2019). Dalam pengujian multikolineritas dapat terlihat dari nilai tolerance dan variance inflation factor (VIF) (Ghozali, 2016).

Tabel 4.

Hasil Uji Multikolineritas

\begin{tabular}{lcc}
\hline Model & Tolerance & VIF \\
\hline CAR &, 211 & 4,750 \\
NPL &, 241 & 4,156 \\
LDR &, 191 & 5,248 \\
BOPO &, 114 & 8,785 \\
Ukuran Perusahaan &, 204 & 4,900 \\
Inflasi &, 668 & 1,497 \\
Pertumbuhan Ekonomi &, 636 & 1,572 \\
Transaksi Internet Banking &, 529 & 1,891 \\
Transaksi Mobile Banking &, 442 & 2,260 \\
\hline
\end{tabular}

Sumber: Data diolah, 2021.

Berdasarkan Tabel 4. nilai tolerance pada variabel independen lebih besar dari 0,10 . Selain itu nilai VIF pada seluruh variabel independen lebih rendah dari 10. Sehingga model regresi dapat dikatakan baik karena terhindar dari multikolineritas. Dalam pengujian autokorelasi, cara yang digunakan yaitu dengan uji Run Test yang akan menilai apakah data residual terjadi secara acak atau tidak (Ghozali, 2016). Berdasarkan Tabel 5, nilai hasil uji autokorelasi menggunakan run test memperlihatkan nilai asymp.sig (2-tailed) sebesar 0,853 sehingga data yang dimiliki dalam penelitian ini dikatakan terbebas dari adanya autokorelasi karena nilai asymp.sig (2-tailed) lebih besar dari 0,05. Uji heteroskedestisitas dilakukan untuk melihat apakah terdapat ketidaksamaan variance residual satu pengamatan ke pengamatan lain (Ghozali, 2016). Dalam pengujian heteroskedestisitas, model regresi yang baik harus tidak terdapat adanya heterokedastisitas (Ramadhayanti, 2019).

Berdasarkan Tabel 6. nilai hasil uji heterokedestisitas menggunakan uji glejser memperlihatkan nilai signifikan pada seluruh variabel independen lebih besar dari yang taraf signifikan yang telah ditetapkan yaitu sebesar 0,05. Sehingga data yang dimiliki dalam penelitian ini dikatakan terbebas dari adanya heterokedastisitas. 
Tabel 5.

Hasil Uji Autokorelasi

\begin{tabular}{lc}
\hline & Unstandardized Residual \\
\hline Test Value &, 00334 \\
Cases $<$ Test Value & 15 \\
Cases $>=$ Test Value & 15 \\
Total Cases & 30 \\
Number of Runs & 15 \\
Z &,- 186 \\
Asymp. Sig. (2-tailed) &, 853 \\
\hline Sumber: Data diolah, 2021.
\end{tabular}

Tabel 6.

Hasil Uji Heteroskedestisitas

\begin{tabular}{lcc}
\hline Model & $\mathrm{T}$ & Sig. \\
\hline (Constant) &,- 573 &, 573 \\
CAR & 2,050 &, 054 \\
NPL &,- 427 &, 674 \\
LDR & 1,760 &, 094 \\
BOPO &, 265 &, 793 \\
Ukuran Perusahaan &, 536 &, 598 \\
Inflasi & 1,097 &, 286 \\
Pertumbuhan Ekonomi & $-1,187$ &, 249 \\
Transaksi Internet Banking &, 971 &, 343 \\
Transaksi Mobile Banking &, 080 &, 937 \\
\hline
\end{tabular}

Sumber: Data diolah, 2021.

Analisis regresi linear berganda digunakan untuk menguji pengaruh beberapa variabel independen terhadap variabel dependen serta mengukur seberapa kuat hubungan dan memperlihatkan arah dari hubungan antara variabel independen dengan variabel dependen (Ghozali, 2016). Berdasarkan Tabel 7. persamaan regresi linear yang dapat diperoleh yaitu:

$$
\begin{aligned}
& Y=7,871+0,144 X_{1}-0,213 X_{2}+0,012 X_{3}-0,078 X_{4}+0,071 X_{5}+0,056 X_{6} \\
& -1,068 X_{7}-2,209 E-11 X_{8}-2,322 E-10 X_{9}
\end{aligned}
$$

Persamaan tersebut menjelaskan bahwa nilai konstanta $(\alpha)$ yang dihasilkan bernilai positif sebesar 7,871 yang memiliki arti apabila variabel independen yang dimiliki oleh bank dalam keadaan konstan atau sama dengan 0 maka nilai profitabilitas akan bertambah sebesar 7,871. Nilai koefisien variabel CAR yang dihasilkan bernilai positif sebesar 0,144 menunjukkan apabila nilai CAR meningkat satu satuan, maka profitabilitas akan bertambah sebesar 0,144. Nilai koefisien variabel NPL yang dihasilkan bernilai negatif sebesar -0,213 menunjukkan apabila nilai NPL meningkat satu satuan, maka profitabilitas akan berkurang sebesar 0,213. Nilai koefisien variabel LDR yang dihasilkan bernilai positif sebesar 0,012 menunjukkan apabila nilai LDR meningkat satu satuan, maka profitabilitas akan bertambah sebesar 0,012 . Nilai koefisien variabel BOPO yang dihasilkan bernilai negatif sebesar $-0,078$ menujukkan apabila nilai BOPO meningkat satu satuan, maka profitabilitas akan berkurang sebesar 0,078. Nilai koefisien variabel ukuran perusahaan yang dihasilkan bernilai positif sebesar 0,071 menunjukkan apabila 
nilai ukuran perusahaan meningkat satu satuan, maka profitabilitas akan bertambah sebesar 0,071. Nilai koefisien variabel inflasi yang dihasilkan bernilai positif sebesar 0,056 menunjukkan apabila nilai inflasi meningkat satu satuan, maka profitabilitas akan bertambah sebesar 0,056.

Tabel 7.

Hasil Uji Regresi Linear Berganda

\begin{tabular}{|c|c|c|c|c|c|}
\hline \multirow[t]{2}{*}{ Model } & \multicolumn{2}{|c|}{$\begin{array}{l}\text { Unstandardized } \\
\text { Coefficients }\end{array}$} & \multirow{2}{*}{\begin{tabular}{l}
$\begin{array}{l}\text { Standardize } \\
\text { d }\end{array}$ \\
Coefficients \\
\multicolumn{1}{|c|}{ Beta } \\
\end{tabular}} & \multirow[t]{2}{*}{$\mathbf{T}$} & \multirow[t]{2}{*}{ Sig. } \\
\hline & B & Std. Error & & & \\
\hline (Constant) & 7,871 & 5,057 & & 1,557 & ,135 \\
\hline CAR &, 144 &, 045 & ,349 & 3,183 & 005 \\
\hline NPL &,- 213 &, 115 &,- 191 & $-1,859$ & 078 \\
\hline LDR &, 012 & 009 &, 153 & 1,325 & 200 \\
\hline BOPO &,- 078 &, 015 &,- 793 & $-5,319$ &, 000 \\
\hline Ukuran Perusahaan &, 071 & ,097 &, 082 &, 732 & ,472 \\
\hline Inflasi &, 056 & 189 &, 018 & ,299 & ,768 \\
\hline Pertumbuhan Ekonomi & $-1,068$ & ,466 &,- 144 & $-2,288$ & 033 \\
\hline Transaksi Internet Banking & $-2,209 \mathrm{E}-11$ &, 000 &,- 018 &,- 265 & ,794 \\
\hline Transaksi Mobile Banking & $-2,322 \mathrm{E}-10$ &, 000 &,- 203 & $-2,689$ &, 014 \\
\hline
\end{tabular}

Nilai koefisien variabel pertumbuhan ekonomi yang dihasilkan bernilai negatif sebesar -1,068 menunjukkan apabila nilai pertumbuhan ekonomi meningkat satu satuan, maka profitabilitas akan berkurang sebesar 1,068. Nilai koefisien variabel transaksi internet banking yang dihasilkan bernilai negatif sebesar 2,209E-11 menunjukkan apabila transaksi internet banking meningkat satu satuan, maka profitabilitas akan berkurang sebesar 2,209E-11. Nilai koefisien variabel transaksi mobile banking yang dihasilkan bernilai negatif sebesar -2,322E-10 menunjukkan apabila transaksi mobile banking meningkat satu satuan, maka profitabilitas akan berkurang sebesar 2,322E-10. Uji F atau uji kelayakan model akan memperlihatkan apakah model regresi layak digunakan dalam penelitian dimana dapat dikatakan layak apabila nilai F dari model tersebut memenuhi kriteria yang ditetapkan (Gani \& Amalia, 2015).

Berdasarkan Tabel 8. dapat dilihat bahwa hasil penelitian ini menunjukkan nilai $F$ hitung sebesar 41,644 dan nilai signifikansi sebesar 0,000. Nilai signifikansi yang dihasilkan dalam penelitian ini lebih kecil dari taraf signifikan yang telah ditentukan yaitu sebesar 0,05 . Sehingga dapat disimpulkan bahwa model regresi tepat untuk digunakan sebagai alat analisis dalam penelitian ini.

Uji koefisien determinasi atau uji $\mathrm{R}^{2}$ dilakukan untuk mengetahui seberapa besar variabel dependen yang dapat dijelaskan oleh variabel independen (Ghozali, 2016). Berdasarkan Tabel 9. dapat dilihat bahwa nilai koefisien determinasi yang dihasilkan sebesar 0,949. Hal ini menunjukkan bahwa sebesar 94,9 persen variasi profitabilitas dipengaruhi oleh CAR, NPL, LDR, BOPO, ukuran perusahaan, inflasi, pertumbuhan ekonomi, transaksi internet banking, dan transaksi mobile banking. Sedangkan sisanya sebesar 5,1 persen dipengaruhi oleh variabel lain diluar penelitian ini. 
Tabel 8.

Hasil Uji F (Uji Kelayakan Model)

\begin{tabular}{lccccc}
\hline \multicolumn{1}{c}{ Model } & Sum of Squares & Df & Mean Square & F & Sig. \\
\hline Regression & 24,188 & 9 & 2,688 & 41,644 &, $000^{\mathrm{b}}$ \\
Residual & 1,291 & 20 &, 065 & & \\
Total & 25,479 & 29 & & & \\
\hline
\end{tabular}

Sumber: Data diolah, 2021.

Tabel 9.

Uji Koefisien Determinasi $\left(R^{2}\right)$

\begin{tabular}{crrrr} 
Model & R & R Square & Adjusted R Square & Std. Error of the Estimate \\
\hline 1 &, $974^{\mathrm{a}}$ &, 949 &, 927 &, 25404 \\
\hline
\end{tabular}

Sumber: Data diolah, 2021.

Uji t dilakukan untuk melihat apakah terdapat pengaruh signifikan dari variabel independen secara parsial terhadap variabel dependen (Ghozali, 2016).

Tabel 10.

Hasil Uji t (Uji Parsial)

\begin{tabular}{|c|c|c|c|c|c|}
\hline \multirow[t]{2}{*}{ Model } & \multicolumn{2}{|c|}{$\begin{array}{l}\text { Unstandardized } \\
\text { Coefficients }\end{array}$} & \multirow{2}{*}{$\begin{array}{c}\text { Standardized } \\
\text { Coefficients } \\
\text { Beta } \\
\end{array}$} & \multirow[t]{2}{*}{$\mathbf{T}$} & \multirow[t]{2}{*}{ Sig. } \\
\hline & B & Std. Error & & & \\
\hline (Constant) & 7,871 & 5,057 & & 1,557 & , 135 \\
\hline CAR &, 144 &, 045 & ,349 & 3,183 & ,005 \\
\hline NPL &,- 213 &, 115 &,- 191 & $-1,859$ & ,078 \\
\hline LDR &, 012 & ,009 &, 153 & 1,325 & ,200 \\
\hline BOPO &,- 078 &, 015 &,- 793 & $-5,319$ &, 000 \\
\hline Ukuran Perusahaan &, 071 & 097 &, 082 &, 732 & ,472 \\
\hline Inflasi &, 056 & , 189 &, 018 & ,299 &, 768 \\
\hline Pertumbuhan Ekonomi & $-1,068$ & ,466 &,- 144 & $-2,288$ & ,033 \\
\hline Transaksi Internet Banking & $-2,209 \mathrm{E}-11$ &, 000 &,- 018 &,- 265 & ,794 \\
\hline Transaksi Mobile Banking & $-2,322 \mathrm{E}-10$ &, 000 &,- 203 & $-2,689$ &, 014 \\
\hline
\end{tabular}

Sumber: Data diolah, 2021.

Berdasarkan Tabel 10. nilai signifikansi uji t dari variabel CAR sebesar 0,005 lebih kecil dari 0,05 dan nilai koefisien regresi dengan arah positif sebesar 0,144. Dapat disimpulkan bahwa variabel CAR memiliki pengaruh positif signifikan terhadap profitabilitas, sehingga hipotesis pertama diterima. Hal ini menunjukkan bahwa semakin meningkatnya angka kecukupan modal bank yang diukur melalui CAR juga akan meningkatkan profitabilitas yang diukur melalui ROA. Hasil penelitian ini juga sesuai dengan packing order. Selain itu, penelitian ini juga sejalan dengan penelitian sebelumnya yang menemukan bahwa CAR memiliki pengaruh positif signifikan terhadap profitabilitas bank (Ambarawati \& Abundanti, 2018; Kossoh et al., 2017; Nugroho et al., 2019).

Nilai signifikansi uji t dari variabel NPL sebesar 0,078 lebih besar dari 0,05 dan nilai koefisien regresi dengan arah negatif sebesar -0,213. Dapat disimpulkan bahwa variabel NPL tidak memiliki pengaruh terhadap profitabilitas, sehingga hipotesis kedua ditolak. Hasil penelitian ini juga tidak sesuai dengan anticipated 
income theory. Tidak adanya pengaruh NPL terhadap profitabilitas dapat diakibatkan adanya kredit kurang lancar atau macet yang nilainya sangat tinggi akan membuat bank tidak mau menyalurkan kredit disebabkan adanya kondisi dimana bank wajib mempersiapkan cadangan dana yang cukup besar dalam pembiayaan kredit bermasalah tersebut yang kemudian membuat bank akan berhati-hati ketika menyalurkan kreditnya (Saputra et al., 2018). Selain itu, kredit bermasalah seperti kredit kurang lancar atau macet dapat terjadi setiap tahun sehingga tidak ada suatu keadaan yang pasti terkait kenaikan atau penurunan NPL yang disertai pada kenaikan atau penurunan ROA (Apriani \& Mansoni, 2019). Penelitian ini juga tidak sejalan dengan penelitian sebelumnya yang menemukan bahwa NPL memiliki pengaruh negatif signifikan terhadap profitabilitas bank (Ambarawati \& Abundanti, 2018; Patni \& Darma, 2017; Sudaryanti et al., 2018). Tetapi penelitian ini sejalan dengan penelitian lain yang menemukan bahwa NPL tidak memiliki pengaruh yang signifikan terhadap profitabilitas bank (Harun, 2016; Matindas et al., 2015; Stevani \& Sudirgo, 2019).

Nilai signifikansi uji t dari variabel LDR sebesar 0,200 lebih besar dari 0,05 dan nilai koefisien regresi dengan arah positif sebesar 0,012. Dapat disimpulkan bahwa variabel LDR tidak memiliki pengaruh terhadap profitabilitas, sehingga hipotesis ketiga ditolak. Hasil penelitian ini tidak sesuai dengan anticipated income theory. Belum maksimalnya penyaluran kredit yang dilakukan bank ke masyarakat juga menjadi faktor mengapa LDR tidak memiliki pengaruh terhadap profitabilitas bank (Saputra et al., 2018). Hasil penelitian ini tidak mendukung penelitian sebelumnya yang menemukan bahwa LDR memiliki pengaruh positif signifikan terhadap profitabilitas bank (Ambarawati \& Abundanti, 2018; Pertiwi \& Susanto, 2019). Namun, penelitian ini sejalan dengan penelitian lain yang menemukan bahwa LDR tidak memiliki pengaruh signifikan terhadap profitabilitas bank (Apriani \& Mansoni, 2019; Stevani \& Sudirgo, 2019).

Nilai signifikansi uji t dari variabel BOPO sebesar 0,000 lebih kecil dari 0,05 dan nilai koefisien regresi dengan arah negatif sebesar -0,078. Dapat disimpulkan bahwa variabel BOPO memiliki pengaruh negatif signifikan terhadap profitabilitas, sehingga hipotesis keempat diterima. Hal ini menunjukkan bahwa semakin menurunnya beban manajemen yang diukur melalui BOPO akan meningkatkan profitabilitas yang diukur melalui ROA. Selain itu, penelitian ini sejalan dengan penelitian sebelumnya yang menemukan bahwa BOPO berpengaruh negatif signifikan terhadap ROA (Pinasti \& Mustikawati, 2018; Stephani et al., 2017).

Nilai signifikansi uji t dari variabel ukuran perusahaan sebesar 0,472 lebih besar dari 0,05 dan nilai koefisien regresi dengan arah positif sebesar 0,071. Dapat disimpulkan bahwa variabel ukuran perusahaan tidak memiliki pengaruh terhadap profitabilitas, sehingga hipotesis kelima ditolak. Penelitian ini tidak sesuai dengan critical resource theory. Besarnya ukuran perusahaan tidak menjamin suatu perusahaan tersebut mampu mendapatkan laba lebih baik daripada perusahaan yang kecil (Putra, 2015). Bahkan perusahaan yang berukuran besar cenderung memerlukan biaya yang lebih banyak dalam melakukan aktivitas operasionalnya (Sari \& Budiasih, 2014). Penelitian ini juga tidak sejalan dengan penelitian sebelumnya yang menemukan bahwa ukuran perusahaan memiliki pengaruh positif signifikan terhadap ROA (Hendrawan \& Lestari, 2017; Hirindukawshala \& 
Kushanipanditharathna, 2017). Namun penelitian ini sejalan dengan penelitian lain yang mengungkapkan bahwa ukuran perusahaan tidak memiliki pengaruh signifikan terhadap ROA (Oktaviarni et al., 2018; Putra, 2015).

Nilai signifikansi uji t dari variabel inflasi sebesar 0,05 lebih besar dari 0,05 dan nilai koefisien regresi dengan arah positif sebesar 0,056. Dapat disimpulkan bahwa variabel inflasi tidak memiliki pengaruh terhadap profitabilitas, sehingga hipotesis keenam ditolak. Penelitian ini tidak sesuai dengan keynesian theory. Tidak berpengaruhnya inflasi disebabkan adanya inflasi tidak memiliki pengaruh pada kegiatan bank dalam penyaluran kredit dikarenakan inflasi akan diatasi oleh upaya dari pemerintah sehingga aktivitas usaha tetap akan berjalan normal (Zattira, 2016). Selain itu, dari data yang diperoleh tidak adanya suatu kepastian terkait rendah atau tingginya inflasi yang disertai oleh penurunan atau kenaikan profitabilitas yang diukur melalui ROA. Hasil penelitian ini tidak sejalan dengan penelitian sebelumnya yang menemukan bahwa inflasi berpengaruh negatif signifikan terhadap profitabilitas bank (Dwi Nurfadillah et al., 2019; Soeharjoto \& Hariyanti, 2019). Namun, penelitian ini sejalan dengan penelitian lain yang mengungkapkan bawah inflasi tidak memiliki pengaruh terhadap profitabilitas bank (S. Setiawan \& Diansyah, 2018; Zattira, 2016).

Nilai signifikansi uji t dari variabel pertumbuhan ekonomi sebesar 0,033 lebih kecil dari 0,05 dan nilai koefisien regresi dengan arah negatif sebesar -1,068. Dapat disimpulkan bahwa variabel pertumbuhan ekonomi memiliki pengaruh negatif signifikan terhadap profitabilitas, sehingga hipotesis ketujuh ditolak. Hal ini menunjukkan bahwa adanya kenaikan pertumbuhan ekonomi yang diukur melalui Produk Domestik Bruto (PDB) akan menurunkan profitabilitas bank yang diukur melalui ROA. Penelitian ini tidak sesuai dengan keynesian theory. Pengaruh negatif signifikan pertumbuhan ekonomi terhadap profitabilitas bank disebabkan kecenderungan masyarakat untuk melakukan investasi dalam sektor riil lebih besar dibanding melakukan saving ketika terjadi pertumbuhan ekonomi yang dinilai dari adanya pertumbuhan PDB (Utu, 2018). Selain itu, adanya krisis ekonomi global di tahun 2008 yang kemudian membuat beberapa negara termasuk Indonesia juga mengalami perlambatan pertumbuhan ekonomi sejak tahun 2009 dan pengaruh dari dampak tekanan finansial dan ketidakpastian politik yang turut mempengaruhi pertumbuhan ekonomi global mengalami perlambatan hingga mengalami kondisi terlemah ditahun 2019 semenjak 10 tahun yang lalu. Akibat kondisi tersebut, membuat bank tidak menyalurkan kredit secara penuh ketika terjadi pertumbuhan ekonomi karena bank masih terus melakukan penyesuaian akibat krisis ekonomi global sehingga adanya peningkatan aktivitas ekonomi masyarakat tidak menciptakan adanya kenaikan pada profitabilitas bank (Fathunnida et al., 2017). Hasil penelitian ini tidak searah dengan penelitian yang mengungkapkan bahwa pertumbuhan ekonomi memiliki pengaruh positif signifikan terhadap profitabilitas bank (Adiyadnya et al., 2016; Sorongan, 2017). Namun, hasil penelitian ini searah dengan penelitian lain yang menemukan bahwa pertumbuhan ekonomi memiliki pengaruh negatif signifikan terhadap profitabilitas bank (Combey \& Togbenou, 2017; Fathunnida et al., 2017).

Nilai signifikansi uji t dari variabel transaksi internet banking sebesar 0,794 lebih besar dari 0,05 dan nilai koefisien regresi dengan arah negatif sebesar - 
2,209E-11. Dapat disimpulkan bahwa transaksi internet banking tidak memiliki pengaruh terhadap profitabilitas, sehingga hipotesis kedelapan ditolak. Hasil penelitian ini tidak sesuai dengan resource based view theory. Tidak berpengaruhnya layanan internet banking terhadap profitabilitas bank disebabkan adanya operasionalisasi layanan internet banking akan menimbulkan biaya infrastruktur, biaya pemeliharaan serta biaya sumber daya manusia yang cukup besar dalam operasionalisasi layanan internet banking dan pendapatan bank yang diperoleh melalui layanan internet banking masih belum bisa menutupi biaya operasional yang telah dikeluarkan untuk penyediaan layanan internet banking (Arif \& Masdupi, 2020). Selain itu, layanan internet banking yang belum maksimal digunakan oleh para nasabah bank (Sinambela \& Rohani, 2017) serta nasabah bank yang sebelumnya menggunakan layanan internet banking mulai berganti dengan menggunakan layanan mobile banking (Arofany \& Tandika, 2019). Penelitian ini tidak mendukung penelitian sebelumnya yang menemukan bahwa internet banking memiliki pengaruh positif signifikan terhadap profitabilitas bank (Wulandari \& Novitasari, 2020; Yasin, 2018). Namun, penelitian ini mendukung penelitian lain yang mengungkapkan bahwa internet banking tidak memiliki pengaruh terhadap profitabilitas bank (Arif \& Masdupi, 2020; Arofany \& Tandika, 2019).

Nilai signifikansi uji t dari variabel transaksi mobile banking sebesar 0,014 lebih kecil dari 0,05 dan nilai koefisien regresi dengan arah negatif sebesar -2,322E10. Dapat disimpulkan bahwa transaksi mobile banking memiliki pengaruh negatif signifikan terhadap profitabilitas, sehingga hipotesis kesembilan ditolak. Adanya kenaikan pada penggunaan mobile banking dalam layanan digital bank yang diukur melalui nilai transaksi mobile banking akan menurunkan profitabilitas bank yang diukur melalui ROA. Penelitian ini tidak sesuai dengan resource based view theory. Pengaruh negatif signifikan mobile banking terhadap profitabilitas bank disebabkan sebagian besar bank tidak menghasilkan volume transaksi mobile banking yang memadai dan pendapatan yang dihasilkan masih lebih kecil daripada investasi yang dilakukan dalam penyelenggaraan layanan mobile banking sehingga terdapat kemungkinan pendapatan yang dihasilkan dari layanan mobile banking masih dibawah breakevent point yang menyebabkan timbulnya biaya yang cukup besar dalam investasi guna penyelenggaraan layanan mobile banking yang kemudian mengurangi keuntungan dari bank dan menyebabkan turunnya nilai ROA (OwusuAntwi et al., 2020). Penelitian ini tidak searah dengan penelitian yang mengungkapkan bahwa mobile banking memiliki pengaruh positif signifikan terhadap profitabilitas bank (Arofany \& Tandika, 2019; Okon \& Amaegberi, 2018). Namun, penelitian ini searah dengan penelitian lain yang menemukan bahwa mobile banking berpengaruh negatif signifikan terhadap ROA (Owusu-Antwi et al., 2020).

\section{SIMPULAN DAN SARAN}

Berdasarkan penelitian yang dilakukan serta pembahasan yang sudah dijelaskan, dapat ditarik kesimpulan bahwa CAR berpengaruh positif signifikan terhadap profitabilitas, sedangkan BOPO, pertumbuhan ekonomi, dan transaksi mobile banking berpengaruh negatif signifikan terhadap profitabilitas. Namun, 
NPL, LDR, ukuran perusahaan, inflasi, dan transaksi internet banking tidak berpengaruh terhadap profitabilitas.

Saran berdasarkan hasil penelitian dan analisis data, pihak manajemen bank diharapkan selalu memperhatikan faktor internal dan eksternal serta perkembangan teknologi untuk menjaga kinerja bank dalam meningkatkan kemampuan bersaing antar industri perbankan. Penelitian selanjutnya diharapkan menggunakan variabel dari faktor internal dan eksternal serta layanan digital bank yang lain diluar penelitian ini serta penilaian profitabilitas selain ROA untuk mendapatkan hasil yang lebih bervariasi agar dapat menggambarkan faktor apa saja yang berpengaruh terhadap profitabilitas bank dan juga dapat menggunakan metode lain ataupun menambah sampel dengan kriteria selain pada penelitian ini serta menambah periode tahun penelitian yang lebih panjang.

\section{REFERENSI}

Adiyadnya, I. N. S., Artini, L. G. S., \& Rahyuda, H. (2016). Pengaruh Beberapa Variabel Ekonomi Makro Terhadap Profitabilitas Dan Return Saham Pada Industri Perbankan Di BEI. E-Jurnal Ekonomi Dan Bisnis Universitas Udayana, 5(8), 2579-2608. https://ojs.unud.ac.id/index.php/EEB/article/view/16233

Ambarawati, I. G. A. D., \& Abundanti, N. (2018). Pengaruh Capital Adequacy Ratio, Non Performing Loan, Loan To Deposit Ratio Terhadap Return On Asset. E-Jurnal Manajemen Universitas Udayana, 7(5), 2441. https://doi.org/10.24843/ejmunud.2018.v07.i05.p04

Anugrah, K., Simanjorang, R. C., Hutabarat, A. R. H., Pakpahan, R. J., \& Sipahutar, T. T. U. (2020). Pengaruh Pertumbuhan Ekonomi dan Inflasi terhadap Profitabilitas pada Perusahaan Makanan dan Minuman di BEI. Owner (Riset Dan Jurnal Akuntansi), 4(2), 442. https://doi.org/10.33395/owner.v4i2.269

Apriani, S. D., \& Mansoni, L. (2019). Pengaruh CAR, LDR dan NPL Terhadap Profitabilitas Pada Bank Yang Terdaftar Di Bursa Efek Indonesia (BEI) (Studi KasuS PT.Bank Bukopin Tbk Tahun 2005-2018). JEMPER (Jurnal Ekonomi Manajemen Perbankan), 1(2), 94. https://doi.org/10.32897/jemper.v1i2.227

Arif, M., \& Masdupi, E. (2020). Pengaruh Internet Banking Terhadap Kinerja Perbankan. Jurnal Ecogen, 3(4), 598-614. http://ejournal.unp.ac.id/students/index.php/pek/index

Arofany, A., \& Tandika, D. (2019). Pengaruh Transaksi Digital Banking, Kualitas Aset, dan Aspek Permodalan terhadap Profitabilitas (Studi Kasus pada Bank Umum yang terdaftar di Bursa Efek Indonesia Tahun 2013-2017). Prosiding Manajemen, $5(1)$, 310-318. http://karyailmiah.unisba.ac.id/index.php/manajemen/article/view/15335

Avrita, R. D., \& Pangestuti, I. R. D. (2016). Analisis Pengaruh CAR, NPL, LDR, 
NIM, dan BOPO Terhadap Profitabilitas Bank (Perbandingan Bank Umum Go Public Dan Bank Umum Non Go Public Di Indonesia Periode Tahun 20112014). Diponegoro Journal of Management, 5(2), 366-378. http://ejournals1.undip.ac.id/index.php/dbr

BI. (2013). Statistik Ekonomi dan Keuangan Indonesia. http://www.bi.go.id

Bilian, F., \& Purwanto. (2017). Analisis Pengaruh CAR, NIM, BOPO, dan LDR Terhadap Profitabilitas Bank Persero. FIRM: Journal of Management Studies, 2(1), 155-168. https://doi.org/10.33021/FIRM.V2I1.157

Cahyani, Y. T. (2018). Pengaruh Inflasi, Suku Bunga (BI Rate), Produk Domestik Bruto (PDB) Terhadap ROA (Studi Pada Bank Pembiayaan Rakyat Syariah (BPRS) di Indonesia Tahun 2009-2016). IQTISHADIA: Jurnal Ekonomi \& Perbankan Syariah, 5(1), 58. https://doi.org/10.19105/iqtishadia.v5i1.1695

Combey, A., \& Togbenou, A. (2017). The Bank Sector Performance and Macroeconomics Environment: Empirical Evidence in Togo. International Journal of Economics and Finance, 9(2), 188. https://doi.org/10.5539/ijef.v9n2p180

Dermawan, W. D., \& Desiana. (2019). Analisis Faktor-Faktor Yang Mempegaruhi Profitabilitas (Studi Pada Bank Umum Konvensional Di Indonesia). Jurnal Akuntansi, 14(1), 32-39. http://jurnal.unsil.ac.id/index.php/jak

Dwi Nurfadillah, S., Amaliah, I., \& Haviz, M. (2019). Pengaruh Inflasi, LPE, dan FDR terhadap ROA Bank Umum Syariah di Indonesia Periode 2003 - 2017. Prosiding Ilmu Ekonomi, 5(1), 166-173. http://karyailmiah.unisba.ac.id/index.php/ekonomi/article/view/15385

Fathunnida, Defung, F., \& Yudaruddin, R. (2017). Dampak Makro Ekonomi terhadap Profitabilitas Bank BPD di Indonesia. Jurnal Manajemen, 9(1), 23. https://doi.org/10.29264/jmmn.v9i1.2429

Gani, I., \& Amalia, S. (2015). Alat Analisis Data: Aplikasi Statistik untuk Penelitian Bidang Ekonomi dan Sosial. PT Andi Offset.

Ghozali, I. (2016). Aplikasi Analisis Multivariate dengan Program IBM SPSS 23. Badan Penerbit Universitas Diponegoro.

Ginting, S. (2019). Analisis Pengaruh CAR, BOPO, NPM dan LDR Terhadap Pertumbuhan Laba Dengan Suku Bunga Sebagai Variabel Moderasi pada Perusahaan Perbankan yang Terdaftar di Bursa Efek Indonesia Periode 2013 2016. Jwem Stie Mikroskil, 9(1), 97-106. https://www.mikroskil.ac.id/ejurnal/index.php/jwem/article/view/616

Gunawan, I., Purnamasari, E. D., \& Setiawan, B. (2020). Pengaruh CAR, NPF, 
FDR, dan BOPO terhadap Profitabilitas (ROA) pada Bank Syariah Bukopin Periode 2012-2018. JASMARK: Jurnal Manajemen Sumber Daya Manusia, Pemasaran Dan Keuangan, 1(1), 19-39. http://doi.org/xxxx/xxxx

Harun, U. (2016). Pengaruh Ratio-Ratio Keuangan CAR, LDR, NIM, BOPO, NPL Terhadap ROA. Jurnal Riset Bisnis Dan Manajemen, 4(1). https://ejournal.unsrat.ac.id/index.php/jrbm/article/view/12352

Hendrawan, Y. P., \& Lestari, H. S. (2017). Faktor - Faktor Penentu Profitabilitas Bank Umum Yang Terdaftar Di Bursa Efek Indonesia (Bei). Jurnal Manajemen Dan Pemasaran Jasa, $9(1), \quad 99$. https://doi.org/10.25105/jmpj.v9i1.1413

Hidayati, A. N. (2014). Pengaruh Inflasi, BI Rate, Dan Kurs Terhadap Profitabilitas Bank Syariah Di Indonesia. An-Nisbah: Jurnal Ekonomi Syariah, 1(1). https://doi.org/10.21274/an.2014.1.1.72-97

Hidayati, L. N. (2015). Pengaruh Kecukupan Modal (CAR), Pengelolaan Kredit (NPL), dan Likuiditas Bank (LDR) Terhadap Probabilitas Kebangkrutan Bank (Studi pada Bank Umum Swasta Devisa yang tercatat di BEI tahun 2009 2013). Jurnal Ilmu Manajemen, 12(1), 38-50. https://doi.org/10.21831/jim.v12i1.11741

Hirindukawshala, \& Kushanipanditharathna. (2017). The Factors Effecting on Bank Profitability. International Journal of Scientific and Research Publications, 7(2), 216. http://www.ijsrp.org/research-paper-0217/ijsrpp6230.pdf

Jorjoga, K. V., \& Murdayanti, Y. (2015). Pengaruh Biaya Operasional Dengan Pendapatan Operasional (BOPO) Dan Dana Pihak Ketiga Terhadap Return On Asset (ROA) Pada Bank Perkreditan Rakyat. Jurnal Ilmiah Wahana Akuntansi, 10(1), 71-87. https://doaj.org/article/046711cf172444b9aea3472b6ac8f3a1

Kasmir. (2015). Bank dan Lembaga Keuangan Lainnya. Rajawali Pers.

Kasmir. (2019). Analisis Laporan Keuangan. PT Raja Grafindo Persada.

Kata Data. (2019). Transaksi E-Commerce Indonesia Terbesar di Asia Tenggara. https://databoks.katadata.co.id/datapublish/2019/10/10/nilai-transaksi-digitalperdagangan-elektronik-indonesia-terbesar-di-asia-tenggara

Kossoh, A. M., Mangantar, M., \& Ogi, I. W. J. (2017). Pengaruh Non Performing Loan (NPL), Capital Adequacy Ratio (CAR), Loan To Deposits Ratio (LDR) Terhadap Profitabilitas Pada Bank Pembangunan Daerah (BPD) Se-Indonesia Tahun 2011-2015. Jurnal EMBA: Jurnal Riset Ekonomi, Manajemen, Bisnis Dan Akuntansi, 5(3). https://doi.org/10.35794/emba.v5i3.17150 
Kurniasari, R. (2017). Analisis Biaya Operasional Dan Pendapatan Operasional (BOPO) Terhadap Return On Assets (ROA). Jurnal Perspektif, XV(1), 71-78. https://doi.org/10.31294/JP.V15I1.2008

Lubis, I. F. (2014). Analisis Hubungan Antara Iflasi Dan Pertumbuhan Ekonomi: Kasus Indonesia. QE Journal, 3(1). https://doi.org/10.24114/QEJ.V3I1.17443

Margaretha, F. (2015). Dampak Electronic Banking Terhadap Kinerja Perbankan Indonesia. Jurnal Keuangan Dan Perbankan, 19(3), 514-524. http://jurkubank.wordpress.com

Mary Ada, O., Gyang, J. Y., \& Tosin, B. D. (2020). Electronic Banking And Performance Of Deposit Money Banks In Nigeria (2011- 2018). International Journal of Business and Applied Social Science, 6(4). https://doi.org/10.33642/ijbass.v6n4p1

Matindas, A. M., Pangemanan, S. S., \& Saerang, D. P. E. (2015). Pengaruh Capital Adequacy Ratio (CAR), BOPO Dan Non Performing Loan (NPL) Terhadap Kinerja Keuangan Perbankan Di Indonesia. Going Concern: Jurnal Riset Akuntansi, 10(1), 52-66. https://doi.org/10.32400/gc.10.1.7367.2015

Noor, H. S., \& Komala, C. (2019). Analisis Indeks Harga Konsumen (IHK) Menurut Kelompok Pengeluaran Nasional Tahun 2018. Jurnal Perspektif, 3(2), 119. https://doi.org/10.15575/jp.v3i2.48

Nugroho, D., Mangantar, M., \& Tulung, J. E. (2019). Pengaruh CAR, BOPO, NIM, Dan NPL Terhadap ROA Industri Bank Umum Swasta Nasional Buku 3 Periode 2014-2018. Jurnal EMBA: Jurnal Riset Ekonomi, Manajemen, Bisnis Dan Akuntansi, 7(3), 4222-4229. https://doi.org/10.35794/emba.v7i3.25038

Okon, A. N., \& Amaegberi, M. A. (2018). Mobile Banking Transactions and Bank Profitability in Nigeria. International Journal of Economics, Commerce, and Management, 6(6), 692-716. http://ijecm.co.uk/wpcontent/uploads/2018/06/6642.pdf

Oktaviarni, F., Murni, Y., \& Suprayitno, B. (2018). Pengaruh Profitabilitas, Likuiditas, Leverage, Kebijakan Dividen Dan Ukuran Perusahaan Terhadap Nilai Perusahaan ( Studi Empiris Perusahaan Sektor Real Estate, Properti , dan Konstruksi Bangunan yang Terdaftar di Bursa Efek Indonesia Tahun 2014-2016 ). Jurnal Akuntansi Universitas Jember-Vol 16 (2), 4(3), 414-428. https://doi.org/10.22441/JIMB.V4I3.5618

Owusu-Antwi, G., Ofei, P., \& Eveland, T. (2020). Mobile Banking: Evidence of Improved Bank Performance in the UAE. International Journal of Economics and Management Studies, 7(12), 47-55. 
https://doi.org/10.14445/23939125/ijems-v7i12p107

Patni, S. S., \& Darma, G. S. (2017). Non Performing Loan, Loan to Deposit Ratio, Net Interest Margin, BOPO, Capital Adequacy Ratio, Return on Asset and Return on Equity. Jurnal Manajemen Bisnis, 14(2), 166-184. http://journal.undiknas.ac.id/index.php/magister-manajemen/

Pertiwi, L., \& Susanto, L. (2019). Faktor Yang Mempengaruhi Profitabilitas Pada Perbankan Yang Terdaftar Di Bei. Jurnal Multiparadigma Akuntansi, 1(2), 282-291. https://doi.org/10.24912/JPA.V1I2.4701

Pinasti, W. F., \& Mustikawati, R. I. (2018). Pengaruh CAR, BOPO, NPL, NIM Dan LDR Terhadap Profitabilitas Bank Umum Periode 2011-2015. Nominal, Barometer Riset Akuntansi Dan Manajemen, 7(1). https://doi.org/10.21831/nominal.v7i1.19365

Pramudyani, D. A., \& Hartono, U. (2018). Pengaruh CAR, BOPO, LDR, Dan Inflasi Terhadap Profitabilitas Pada Bank BUSN Non Devisa Yang Terdaftar Di Indonesia Periode 2012 - 2016. UNEJ E-Proceeding. https://jurnal.unej.ac.id/index.php/prosiding/article/view/9213

Putra, A. A. W. Y. (2015). Pengaruh Leverage, Pertumbuhan Penjualan dan Ukuran Perusahaan Terhadap Profitabilitas | E-Jurnal Manajemen. E-Jurnal Manajemen, $4(7)$. https://ojs.unud.ac.id/index.php/Manajemen/article/view/12700

Ramadhayanti, A. (2019). Aplikasi SPSS untuk Penelitian dan Riset Pasar. PT Alex Media Computindo.

Riyadi, S. (2015). Banking Assets and Liablility Management. Lembaga Penerbit Fakultas Ekonomi Universitas Indonesia.

Saputra, A., Arfan, M., \& Saputra, M. (2018). Pengaruh Capital Adequacy Ratio, Net Interest Margin, Loan To Deposit Ratio Dan Non Performing Loan Terhadap Profitabilitas Bank Umum Non Devisa Di Indonesia Periode 20142016. Jurnal Perspektif Ekonomi Darussalam, 4(2), 199-212. https://doi.org/10.24815/jped.v4i2.12573

Sari, N. M. V., \& Budiasih, I. G. A. . (2014). Pengaruh Debt to Equity Ratio, Firm Size, Inventory Turnover Dan Assets Turnover Pada Profitabilitas. E-Jurnal Akuntansi, 6(2), 261-273. https://ojs.unud.ac.id/index.php/Akuntansi/article/view/7930

Setiawan, N., Rahman, I. F., \& Kembuan, D. T. (2018). Analisis Pengaruh Karakteristik Spesifik Bank Terhadap Fungsi Intermediasi Pada Perbankan Yang Terdaftar Di Bursa Efek Indonesia Tahun 2013 Sampai Tahun 2017. 
Jurnal Riset Akuntansi Dan Keuangan, 6(2), 187-210. https://doi.org/10.17509/jrak.v6i2.11645

Setiawan, S., \& Diansyah. (2018). Pengaruh CAR, BOPO, NPL, Inflasi Dan Suku Bunga Terhadap Profitabilitas Pada Bank Umum Konvensional Yang Terdaftar Di Bursa Efek Indonesia. Media Manajemen Jasa, 6(2), 1-17. www.journal.uta45jakarta.ac.id

Siahaan, D., \& Asandimitra, N. (2018). Pengaruh Likuiditas Dan Kualitas Aset terhadap Profitabilitas pada Bank Umum Nasional (Studi pada Bursa Efek Indonesia Periode 2010-2014). BISMA (Bisnis Dan Manajemen), 9(1), 1. https://doi.org/10.26740/bisma.v9n1.p1-12

Sinambela, E., \& Rohani. (2017). Pengaruh Penyediaan Layanan Internet Banking Terhadap Kinerja Keuangan Perbankan di Bursa Efek Indonesia. When Fintech Meets Accounting: Opportunity and Risk , 6, 87-94. http://fkbi.akuntansi.upi.edu/

Soares, P., \& Yunanto, M. (2018). The Effect Of NPL, CAR, LDR, OER And NIM To Banking Return On Asset. International Journal of Economics, Commerce and Management United Kingdom, VI(3), 40-55. http://ijecm.co.uk/

Soeharjoto, \& Hariyanti, D. (2019). Pengaruh makro ekonomi dan fundamental perusahaan terhadap kinerja perbankan syariah di Indonesia. Jurnal Akuntansi Keuangan Dan Manajemen, 1(1), 1-8. https://doi.org/10.35912/jakman.v1i1.1

Sorongan, F. A. (2017). Analisis Pengaruh CAR, LOAN, GDP Dan Inflasi Terhadap Profitabilitas Bank Di Indonesia. Jurnal Akuntansi, 10(2), 116-126. https://doi.org/10.25170/jara.v10i2.42

Stephani, R., Adenan, M., \& Hanim, A. (2017). Analisis Pengaruh Rasio Keuangan Terhadap Kinerja Bank Umum di Indonesia. E-Journal Ekonomi Bisnis Dan Akuntansi, 4(2), 192. https://doi.org/10.19184/ejeba.v4i2.5825

Stevani, \& Sudirgo, T. (2019). Analisis CAR, BOPO, NPL, Dan LDR Terhadap ROA Perusahaan Perbankan. Jurnal Paradigma Akuntansi, 1(3), 863-871. https://doi.org/10.24912/JPA.V1I3.5590

Sudaryanti, D. S., Sahroni, N., \& Kurniawati, A. (2018). Analisa Pengaruh Mobile Banking Terhadap Kinerja Perusahaan Sektor Perbankan Yang Tercatat Di Bursa Efek. Jurnal Ekonomi Manajemen, 4(2), 96-107.

Sugito, H. B., \& Winarno, A. (2019). Pengaruh Variabel Eksternal Terhadap Return On Aset (Studi Kasus Bank Umum Syariah Yang Terdaftar Di BEI, Periode 2012-2017. Jurnal Manajemen Indonesia, 19(2), 207. https://doi.org/10.25124/jmi.v19i2.2157 
Sugiyono. (2015). Metode Penelitian Kuantitatif, Kualitatif, dan R\&D. Alfabeta.

Sutrisno, B. (2017). Determinan Profitabilitas Bank Umum Terdaftar di Bursa Efek Indonesia. Esensi: Jurnal Bisnis Dan Manajemen, 8(1), 41-48. https://doi.org/10.15408/ess.v8i1.6554

Trihastuti, A., \& Dewi, M. S. (2016). Penilaian Kualitas Kinerja keuangan Perusahaan Perbankan Antara Sebelum dan Sesudah Merger Studi Kasus Pada PT. Bank Mandiri, Tbk. JEA17: Jurnal Ekonomi Akuntansi, 1(01), 21-36. https://doi.org/10.30996/jea17.v1i01.646

Utu, L. (2018). Effects Of Extern Factors On Return On Asset (ROA) In Banking Industry In Indonesia Stock Exchange. International Journal of Scientific \& Engineering Research, 9(12), 1116-1121.

Vernanda, S. D., \& Widyarti, E. T. (2016). Analisis Pengaruh CAR, LDR, NPL, BOPO, dan SIZE Terhadap ROA (Studi pada Bank Umum Konvensional yang Terdaftar di Bursa Efek Indonesia Periode 2010-2015). Diponegoro Journal of Management, 5(3), 1-13. https://ejournal3.undip.ac.id/index.php/djom/article/viewFile/14879/14395

Wulandari, S., \& Novitasari, N. (2020). Pengaruh Internet Banking, Risiko Kredit dan Ukuran Perusahaan Terhadap Kinerja Keuangan Perbankan Yang Terdaftar Di Bursa Efek Indonesia Periode 2017 - 2019. Jesya (Jurnal Ekonomi \& Ekonomi Syariah), 4(1). https://doi.org/10.36778/jesya.v4i1.327

Yasin, M. A. (2018). Impact of Internet Banking on Financial Performance: Empirical Evidence from Ethiopia Banks. Research Journal of Finance and Accounting, 9(11), 1-10. https://www.iiste.org/Journals/index.php/RJFA/article/view/42943/44236

Yohani, \& Dita, F. I. (2019). Pengaruh Internet Banking Terhadap Kinerja Keuangan Pada Bank Umum Konvensional Yang Terdaftar Di Bursa Efek Indonesia (Periode 2015 - 2018). Jurnal Ilmiah Neraca FEB-UMPP, 15(1), 30-40. http://jurnal.stiemuhpekalongan.ac.id/index.php/nrc/article/view/129

Yultiara, D., \& Nurdin. (2018). Pengaruh Internet Banking, CAR, BOPO dan NPL terhadap Profitabilitas Perbankan yang Terdaftar di Bursa Efek Indonesia (BEI) Periode 2016. Prosiding Manajemen, 4(1), 28-33. http://karyailmiah.unisba.ac.id/index.php/manajemen/article/view/8984

Zattira, R. (2016). Pengaruh NPL, CAR, Inflasi, Suku Bunga Dan Kurs Melalui Jumlah Penyaluran Kredit Terhadap Profitabilitas Perbankan. Relasi : Jurnal Ekonomi, 12(2), 730-754. https://doi.org/10.31967/RELASI.V12I2.101 